\title{
ANALiSis Feature dan MACHINe LEARNing UNTUK PENCARIAN WEB
}

\author{
Anggun Cipta ${ }^{1}$, Syahmi Putra ${ }^{2}$ \\ STMIK KADIRI \\ Jurusan Sistem Informasi \\ acipta@yahoo.co.id ${ }^{1}$ syahmi06@yahoo.com²
}

\begin{abstract}
The use of website socialization is increasingly still for that amount of information growing rapidly, the harder it is to find the information within the specified time. The main searches for searches that are irrelevant or incompatible with user preferences, keyword based searches, short questions. In this paper, we will examine the various features used in information retrieval. We will also discuss the relevance of web pages with users. We have classified by feature. In the end we will compare different techniques and their pros and cons are discussed.
\end{abstract}

Keywords-Machine learning; Search engine; Information retrieval; User intention,Web Mining

\section{Pendahuluan}

Karena semakin banyak informasi yang tersedia di world wide web, itu menjadi terlalu sulit bagi mesin pencari untuk menjaga indeks pencarian yang up-to-date dan komprehensif. Ada masalah kelebihan informasi, karena yang pencari tidak mendapatkan hasil yang relevan. Kebanyakan mesin pencari hanya menggunakan kata kunci sebagai permintaan. Alasan utama untuk hasil pencarian yang tidak relevan adalah mesin pencari berbasis kata kunci. Karena ambiguitas semantik, kata yang sama memiliki banyak arti yang berbeda, hasil pencarian tidak sesuai dengan kebutuhan pengguna. Karena pengguna yang berbeda mungkin mencari informasi yang berbeda dan bahkan pengguna yang sama mungkin mencari informasi yang berbeda pada titik waktu yang berbeda. Jadi, memahami tujuan pencarian pengguna dan menampilkan hasil sesuai dengan niat pengguna pasti akan meningkatkan kualitas hasil pencarian. Teknik penambangan web dapat digunakan untuk memecahkan masalah kelebihan informasi secara langsung atau tidak langsung. Penambangan web menggunakan teknik penambangan data untuk secara otomatis menemukan dan mengekstrak informasi dari dokumen web dan layanan [1].

Machine Learning adalah bidang ilmu komputer yang memberi komputer kemampuan untuk belajar tanpa secara eksplisit diprogram [2]. Teknik pembelajaran mesin dapat diterapkan dalam proses penambangan web untuk meningkatkan kualitas pencarian.

\section{LANDASAN TEORI}

Di bagian ini, kami meninjau berbagai fitur yang ditemukan berguna dalam memutuskan apakah halaman web relevan atau tidak relevan dengan pengguna web.

\section{A. Fitur Halaman Web}

\section{- Konten tekstual di halaman web}

Isi halaman adalah fitur yang paling jelas dalam menentukan relevansi halaman. Tetapi karena berbagai suara di halaman web, menggunakan langsung konten halaman sebagai tas kata-kata untuk semua istilah bukanlah pilihan yang baik. Oleh karena itu, ada berbagai metode pemilihan fitur yang dikembangkan seperti perolehan informasi, informasi timbal balik, frekuensi dokumen, dan uji $\mathrm{x}^{2}$. 
- $\quad$ Tag HTML

Halaman web yang ditulis dalam HTML selain dari konten tekstual mengandung tag HTML yang memberikan informasi tambahan. Tag HTML seperti judul, body, anchor, heading, label, URL banyak digunakan. Kata-kata dan frasa yang muncul dalam judul atau tag judul diberikan bobot yang lebih tinggi. Fitur lain yang penting adalah URL halaman web, itu unik, bermakna dan dapat membantu mengidentifikasi domain halaman web [8].

\section{B. Fitur Tetangga}

Fitur yang ditemukan berguna dari tetangga mencakup label, konten parsial yaitu teks tautan, teks teks tautan di sekitarnya, judul, header, dan konten lengkap. Label yang paling sering digunakan fitur tetangganya dan anchor text adalah fitur yang jarang digunakan [8].

\section{Analisis Tautan}

Tautan web telah banyak digunakan untuk memberikan informasi penting tentang halaman web. Algoritma yang banyak digunakan untuk ini adalah (Hiper-Induced Topic Search) algoritma HITS dan algoritma PageRank. Dalam algoritma PageRank [10], PageRank dihitung dengan membobot setiap tautan masuk ke halaman secara proporsional dengan kualitas halaman yang berisi tautan-dalam. Kualitas halaman pengarah ini juga ditentukan oleh algoritme PageRank. PageRank halaman p dihitung secara rekursif sebagai follwws:

$$
\operatorname{PageRank}(p)=(1-d)+d * \sum \text { all } q \text { linking to } p\left[\frac{\operatorname{PageRank}(q)}{c(q)}\right]
$$

dimana $\mathrm{d}$ adalah faktor redaman antara $0 \& 1, \mathrm{c}(\mathrm{q})$ adalah jumlah tautan keluar dalam $\mathrm{q}$.

Skor PageRank dari suatu halaman web tinggi jika halaman tersebut direferensikan oleh banyak halaman dan skornya bahkan lebih tinggi jika halaman referensi ini juga berkualitas baik. Skor PageRank dihitung secara rekursif, sehingga sangat mahal secara komputasi.

Di (Pencarian Topik yang Diinduksi Hyperlink) [9] algoritma HITS, halaman otoritas adalah halaman berkualitas tinggi yang terkait dengan topik tertentu atau permintaan pencarian. Halaman Hub adalah halaman-halaman yang tidak perlu otoritas sendiri tetapi yang menyediakan petunjuk ke halaman otoritas lain. Halaman di mana banyak halaman lainnya menunjukkan otoritas yang baik, dan halaman yang menunjuk ke banyak halaman lain harus menjadi hub yang baik. Nilai otoritas dan skor hub untuk setiap halaman web dihitung sebagai berikut:

$$
\begin{aligned}
& \text { Authority Score }(p)=\sum \text { all q linking to } q(\text { Hub Score }(q)) \\
& \operatorname{HubScore}(p)=\sum \text { all } r \text { linking to } p(\text { Authority Score }(r))
\end{aligned}
$$

Halaman memiliki nilai otoritas yang tinggi jika ditandai oleh banyak hub dan halaman memiliki skor hub yang tinggi, jika itu menunjuk ke banyak otoritas. Tautan web penting lainnya adal ah jangkar teks, itu adalah teks yang menggambarkan tautan. Ini adalah teks yang dapat diklik dari tautan keluar di halaman web. Teks jangkar memberikan deskripsi yang bagus tentang halaman target.

\section{KASIFIKASI}

A. Konten dan Tautan Laman Web sebagai Fitur

Michael mengusulkan pendekatan pembelajaran mesin yang menggabungkan konten berbasis web dan fitur berbasis struktur web. Dua teknik pembelajaran mesin feedforward / jaringan saraf backpropagation dan dukungan mesin vektor diimplementasikan dan dibandingkan dengan pendekatan tradisional - pendekatan berbasis kata kunci dan pendekatan berbasis leksikon. Pendekatan web-fitur 
yang diusulkan mengekstrak semua istilah dari suatu halaman dan membandingkannya dengan leksikon domain. Total 14 skor fitur ditentukan [3]:

Fitur berbasis Konten Halaman

Judul halaman $\mathrm{p}=$ Jumlah istilah dalam judul halaman $\mathrm{p}$ ditemukan dalam leksikon domain.

Frekuensi frekuensi inverse dokumen halaman $\mathrm{p}$ [TFIDF] = Jumlah TFIDF dari istilah di halaman $\mathrm{p}$ ditemukan dalam leksikon domain. Isi halaman fitur berbasis tetangga Judul dan skor TFIDF dari dokumen tetangga ditentukan seperti di atas. Halaman Sibling adalah halaman-halaman yang ditunjuk oleh salah satu orang tua halaman $\mathrm{p}$.

Judul semua halaman Masuk q ke $\mathrm{p}=$ Rata-rata (jumlah istilah dalam judul halaman q ditemukan dalam leksikon domain) untuk semua halaman masuk q dari p.

TFIDF dari semua Halaman masuk $\mathrm{q}$ to $\mathrm{p}=$ Rata-rata (jumlah TFIDF dari istilah di halaman $\mathrm{q}$ ditemukan dalam leksikon domain) untuk semua halaman masuk q dari $\mathrm{p}$.

Judul semua halaman keluar $\mathrm{q}$ ke $\mathrm{p}=$ Rata-rata (jumlah istilah dalam judul halaman $\mathrm{r}$ ditemukan dalam leksikon domain) untuk semua halaman keluar $r$ dari $\mathrm{p}$.

Feedforward / backpropagation neural network (FF / BP NN) dan Vektor Dukungan Vector Machine (SVM) dibandingkan terhadap dua pendekatan tradisional yaitu pendekatan berbasis leksikon (LEXICON) dan pendekatan mesin vektor dukungan berbasis kata kunci (SVM-WORD).

Pendekatan Machine Learning

Di Feedforward / backpropagation neural network classifier - (FF / BP NN) jaringan syaraf pengklasifikasian teks dibuat dengan tiga lapisan yaitu lapisan input, lapisan tersembunyi dan lapisan output. Lapisan input terdiri dari unit ambang dan 14 node yang sesuai dengan 14 skor fitur dari setiap halaman. Lapisan keluaran terdiri dari satu simpul yang menentukan relevansi suatu halaman. Jumlah simpul dalam lapisan tersembunyi ditetapkan menjadi 16 dan tingkat pembelajaran pada 0,10 . Setelah menginisialisasi jaringan, pelatihan dan penyeteman dilakukan. Untuk pengujian, setiap dokumen pengujian dilewatkan ke jaringan untuk memprediksi apakah dokumen itu relevan. Prediksi direkam dan dihitung untuk mengukur kinerja.

SVM Text Classifier- Classifier SVM juga menggunakan set skor fitur yang sama. Fungsi kernel linear telah dipilih untuk pengklasifikasi SVM. Di sini, dataset pelatihan terdiri dari vektor dari 14 fitur yang dipilih dan disajikan kepada SVM untuk mempelajari bobot fitur. Untuk pengujian, SVM mencoba memprediksi apakah setiap dokumen dalam set pelatihan relevan atau tidak. Hasilnya direkam dan digunakan untuk mengukur kinerja. Untuk bidang medis evaluasi dipilih sebagai domain. Sebuah halaman web yang diuji dan leksikon medis yang dibuat dalam penelitian sebelumnya digunakan [11].

Pendekatan Benchmark

LEXICON- Dalam pendekatan berbasis leksikon, skor TFIDF dihitung untuk istilah-istilah yang ditemukan dalam leksikon medis. Arizona Noun Phraser (AZNP) [13] digunakan untuk mengekstraksi frase nomina dari setiap dokumen dan frasa ini dibandingkan dengan leksikon. Skor kesamaan Jaccard dihitung untuk setiap dokumen dalam set pelatihan dan leksikon. Skor Jaccard secara luas digunakan skor kesamaan dalam pengambilan informasi [12]. Nilai ambang yang memiliki akurasi tertinggi membagi dokumen menjadi relevan dan tidak relevan dipilih untuk pengujian.

Pendekatan Mesin Pendukung Vektor Kata Kunci berdasarkan-Pertama-tama preprocessing dari dokumen dilakukan yang melibatkan tokenization, penghapusan stop-word, stemming menggunakan Porter's stemmer [14]. Setelah tahap preprocessing setiap dokumen direpresentasikan sebagai vektor kata kunci, yang kemudian digunakan untuk pengujian dan pelatihan. 
Untuk evaluasi, 50 metodologi validasi silang digunakan. Presisi, ingat, F-measure, akurasi dan waktu diukur untuk semua empat pendekatan [3].

$$
\begin{aligned}
& \text { Precision }=\frac{n \text { document correctly classified as positive by system }}{n \text { all document classified as positive by system }} \\
& \text { recall }=\frac{n \text { document correctly classified as posotive by system }}{n \text { positive document as testing set }} \\
& F-\text { measure }=\frac{2 * \text { precision } * \text { recall }}{\text { precision+recall }}
\end{aligned}
$$

Hasil eksperimen pada keakuratan, presisi, recall dan F-measure diberikan di bawah ini.

\begin{tabular}{|c|l|l|l|l|l|}
\hline Approach & $\begin{array}{c}\text { Accuracy } \\
(\%)\end{array}$ & $\begin{array}{l}\text { Precision } \\
\text { (macro/ } \\
\text { micro)(\%) }\end{array}$ & $\begin{array}{l}\text { Recall } \\
\text { (macro/ } \\
\text { micro)(\%) }\end{array}$ & $\begin{array}{l}\text { F-measure } \\
\text { (macro/ } \\
\text { micro) (\%) }\end{array}$ & $\begin{array}{l}\text { Time } \\
\text { (min) }\end{array}$ \\
\hline LEXICON & 80.80 & $63.40 / 63.95$ & $60.52 / 62.50$ & $0.6005 / 0.6322$ & 7.45 \\
\hline $\begin{array}{c}\text { SVM- } \\
\text { WORD }\end{array}$ & 87.80 & $87.97 / 94.94$ & $55.08 / 56.82$ & $0.6646 / 0.7109$ & 382.55 \\
\hline NN-WEB & 89.40 & $81.38 / 82.38$ & $76.19 / 76.14$ & $0.7614 / 0.7913$ & 103.45 \\
\hline SVM-WEB & 87.30 & $85.35 / 86.24$ & $61.99 / 61.74$ & $0.7049 / 0.7196$ & 37.60 \\
\hline
\end{tabular}

Hasil dari eksperimen tersebut dibahas sebagai berikut: Pendekatan SVM berbasis kata kunci membutuhkan waktu yang terlama karena setiap dokumen direpresentasikan sebagai vektor besar kata kunci yang menciptakan dimensi tinggi untuk pengklasifikasi. Pendekatan berbasis leksikon membutuhkan waktu paling sedikit, karena hanya perlu menghitung TFIDF dan skor kesamaan untuk setiap dokumen dan menentukan ambang batas, yang tidak memerlukan pemrosesan yang rumit. NN classifier membutuhkan waktu yang lebih lama daripada pendekatan berbasis SVM-WEB karena jaringan syaraf harus dilatih dalam beberapa iterasi.

Pendekatan berdasarkan kata kunci membutuhkan banyak contoh pelatihan. Lebih sedikit data pelatihan diperlukan untuk leksikon dan pendekatan berbasis web.

Pendekatan SVM berbasis kata kunci dilakukan lebih baik daripada pendekatan berbasis leksikon. Fitur web yang diusulkan mendekati NN-WEB dan SVM-WEB dilakukan dengan efektivitas yang sebanding. Kedua pendekatan fitur web pembelajaran mesin dilakukan dengan efektivitas yang lebih tinggi daripada dua pendekatan pembandingan yaitu, pendekatan berbasis kata -VM (SVM-WORD) dan pendekatan berbasis leksikon (LEXICON).

Arah pekerjaan masa depan adalah untuk memeriksa mana dari 14 fitur yang lebih penting daripada yang lain dalam menentukan relevansi halaman web. Kemungkinan lain dari pekerjaan di masa depan adalah menentukan apakah pendekatan gabungan kata kunci dan fitur web akan berkinerja lebih baik daripada menggunakan kata kunci atau fitur web saja. Akhirnya, ruang lingkupnya adalah untuk menyelidiki bagaimana metode klasifikasi yang diusulkan dapat digunakan dalam aplikasi lain seperti manajemen pengetahuan dan manajemen konten web.

\section{B. Konsep sebagai Fitur}

Karya ini menyajikan pendekatan hibrida yang menggunakan profil berbasis dokumen dan berbasis konsep untuk personalisasi ulang hasil yang diperoleh dari mesin pencari yang ada. Preferensi pengguna telah diekstraksi dari kueri sebelumnya dan data klik-tayang untuk memprediksi preferensi dokumen untuk individu. Ekstensi browser ditambahkan ke browser yang memantau pencarian pengguna, penelusuran, dan informasi klik-tayang. Ekstensi peramban ini akan menyimpan kueri dan 
hasil yang diperoleh untuk permintaan itu sebagai halaman hasil mesin pencari (SERPs) dan data kliktayang. Data klik-tayang menyampaikan informasi tentang hasil mana yang diklik pengguna, yang pada gilirannya mencerminkan preferensi pengguna. SERPs terdiri dari urutan dokumen yang diwakili oleh triplet: judul, ringkasan isi dan URL sumber.

Setiap hasil yang dikembalikan oleh mesin pencari web diwakili dalam bentuk potongan-web. Websnippet akan terdiri dari judul, ringkasan konten dan URL sumber. Web ini., Cuplikan akan digunakan lebih lanjut untuk mengekstraksi konsep.

Database pengguna terdiri dari agregasi konsep. Konsep adalah sekelompok kata yang mewakili preferensi pengguna - dan kesukaannya. Setiap kelompok kata-kata yang sering muncul di seluruh websnippet akan dianggap sebagai konsep. - Kelompok kata yang disebut sebagai kata kunci dipisahkan dan - dukungan untuk masing-masing ditentukan sebagai berikut [4]:

$\operatorname{Support}(c i)=\frac{s f(c i)}{n} *|C i|$

sf (ci) adalah frekuensi cuplikan dari kata kunci ci, $\mathrm{n}$ adalah jumlah web-snippet yang dikembalikan dan | ci | adalah jumlah kata dalam ci, Jika dukungan untuk ci lebih besar dari nilai ambang, maka ci akan dianggap sebagai konsep. Dengan cara ini, cuplikan web akan disimpan sebagai kumpulan konsep daripada menyimpan judul, URL, ringkasan secara terpisah.

Selanjutnya, preferensi pengguna diekstraksi dari diklik serta potongan-potongan web yang tidak diklik. Semua konsep dari web-snippet disusun dalam bentuk pohon (ontologi) menggunakan hubungan berbeda yang ada di antara konsep-konsep ini. Dua jenis hubungan dipertimbangkan: hubungan kesamaan dan hubungan orangtua-anak.

Setelah pembuatan pohon ini, bobot yang terkait dengan konsep milik klik-klip web bertambah dan peningkatan bobot ini mempengaruhi konsep lain yang berhubungan dengan konsep-konsep ini. Setelah mengekstraksi preferensi pengguna dari cuplikan web yang diklik, rangkuman ulang cuplikan web dilakukan dengan menetapkan skor untuk mereka.

$\operatorname{score}(S 1)=\sum f c k * w(c k)$

fck adalah frekuensi kemunculan ck dalam snippet.

$\mathrm{N}$ adalah jumlah total konsep yang termasuk ke dalam cuplikan web itu.

Kekuatan dari penelitian ini adalah bahwa informasi konsep diperoleh dari data penelusuran pengguna oleh karena itu tidak ada intervensi manual pengguna yang diperlukan dan juga menyediakan pembelajaran dinamis yang mendukung perubahan kebutuhan pengguna dengan waktu. Ruang lingkup masa depan dalam penelitian ini adalah untuk memperkenalkan konteks dan pemfilteran kolaboratif. Dan lebih banyak hubungan dapat dikaitkan dengan konsep.

\section{URL sebagai Fitur}

Dalam teknik pembelajaran mesin kerja ini digunakan dan hanya fitur URL yang dianggap untuk klasifikasi otomatis halaman web ke dalam kategori mereka [5]. Keuntungan menggunakan URL adalah bahwa URL itu unik, bermakna, dapat dibaca manusia dan dapat membantu mengidentifikasi kategori halaman web. Tidak perlu mengambil dan memroses halaman web sehingga lebih cepat juga. Tiga teknik pembelajaran mesin yang digunakan yaitu: Naïve Bayes classifier, Support Vector Machine dan RBF. Dataset yang digunakan adalah WEBKB dan diunduh dari repositori UCI. Program Java digunakan untuk mengurai URL menjadi token, untuk memilih fitur dari URL saja dan kemudian masing-masing pengklasifikasi pembelajaran mesin belajar aturan klasifikasi selama fase pelatihan.

Hasil kinerja pengklasifikasi dengan fitur URL untuk data uji. 


\begin{tabular}{|l|l|l|l|l|l|}
\hline $\begin{array}{l}\text { Machine } \\
\text { Learning }\end{array}$ & $\begin{array}{l}\text { No.of } \\
\text { Positive } \\
\text { examples } \\
\text { correctly } \\
\text { classified }\end{array}$ & $\begin{array}{l}\text { No. of } \\
\text { Negative } \\
\text { examples } \\
\text { classified } \\
\text { as } \\
\text { positive }\end{array}$ & $\begin{array}{l}\text { No.of } \\
\text { examples } \\
\text { classified } \\
\text { as } \\
\text { negative }\end{array}$ & $\begin{array}{l}\text { No. of } \\
\text { positive } \\
\text { examples } \\
\text { classified } \\
\text { as } \\
\text { negative }\end{array}$ & $\begin{array}{l}\text { Overall } \\
\text { Success } \\
\text { rate }\end{array}$ \\
\hline $\begin{array}{l}\text { Naive } \\
\text { Bayes } \\
\text { Classifier }\end{array}$ & 50 & 93 & 27 & 80 & 0.308 \\
\hline SVM & 48 & 73 & 47 & 82 & 0.38 \\
\hline $\begin{array}{l}\text { RBF } \\
\text { Network }\end{array}$ & 130 & 120 & NIL & NIL & 0.52 \\
\hline
\end{tabular}

Hasil menunjukkan bahwa: RBF memiliki tingkat keberhasilan yang lebih baik tetapi mengklasifikasikan semua instance ke dalam kategori tunggal dan jika jumlah instance negatif meningkatkan penurunan kinerja. Ini tidak berguna untuk contoh negatif. Pengklasifikasi SVM berkinerja lebih baik daripada dua pengklasifikasi lainnya. Penggolongan Naive Bayes menunjukkan tingkat keberhasilan yang dapat diterima. Jadi, terbukti bahwa fitur URL cukup untuk klasifikasi halaman web otomatis menggunakan teknik pembelajaran mesin.

Arah pekerjaan masa depan adalah mencoba mengklasifikasikan halaman yang diklasifikasikan negatif dengan fitur URL menggunakan metode klasifikasi berdasarkan konten untuk memiliki akurasi klasifikasi yang lebih baik.

\section{Noun sebagai Fitur}

Ini mengusulkan metode untuk mengekstrak niat pengguna dari log pencarian web dan membangun peta niat yang mewakili kebutuhan informasi mereka [6]. Log pencarian pengguna berisi permintaan dan URL yang diklik terkait. URL yang diklik ini disempurnakan untuk menghapus duplikat dan halaman kesalahan URL. Fitur intensi dipilih dari dokumen web ini. Kata benda dipilih sebagai fitur untuk mengekstrak niat. Kata benda diambil dari setiap dokumen web melalui analisis morfem tunggal dan klausa subordinat. Nilai TF / IDF digunakan untuk meletakkan bobot pada kata-kata yang mengandung lebih banyak informasi.

$w_{i j}=t f_{i j} * \log \left(\frac{N}{d f_{j}}\right)$

$\mathrm{W}_{\mathrm{ij}}$ berarti bobot fitur $\mathrm{jth}$ dalam log pencarian engan yang berisi niat pengguna. $\mathrm{tf}_{\mathrm{ij}}$ berarti frekuensi bahwa fitur $\mathrm{j}$ disajikan dalam log pencarian engan. dfj adalah jumlah data dengan fitur engan. Satu set niat pengguna diklasifikasikan ke dalam kategori menggunakan algoritma pengelompokan (selforganizing map) SOM. Sekarang niat pengguna diekstrak dari setiap kluster menggunakan kata kunci yang mewakili kluster. Niat dengan skor tinggi di setiap kategori dipilih sebagai niat perwakilan. Selanjutnya, peta niat dibangun. Intention map mengadopsi model skema, metode representasi pengetahuan psikologi kognitif untuk mewakili niat pengguna. Untuk percobaan weblog pencarian mesin komersial komersial digunakan. Eksperimen perilaku mengukur ekspresivitas dan keefektifan peta

Hasil percobaan diberikan di bawah ini: 


\begin{tabular}{|l|l|l|l|l|}
\hline Query & $\begin{array}{l}\text { Expressive } \\
\text { ness }\end{array}$ & $\begin{array}{l}\text { Intention } \\
\text { Map } \\
\text { Effectiven } \\
\text { ess } \\
\text { means(SD } \\
\text { ness }\end{array}$ & $\begin{array}{l}\text { General } \\
\text { Effective } \\
\text { means } \\
(\mathrm{SD})\end{array}$ & $\begin{array}{l}\text { Statistically } \\
\text { differences }\end{array}$ \\
\hline Bag & 5.66 & $5.76(1.19)$ & $\begin{array}{l}4.14(1.6 \\
0)\end{array}$ & $\begin{array}{l}\mathrm{t}(36)=5.025, \mathrm{p}=0.0 \\
00\end{array}$ \\
\hline $\begin{array}{l}\text { Dream } \\
\text { Fishing- } \\
\text { tackle }\end{array}$ & 5.62 & $5.86(1.08)$ & $\begin{array}{l}4.95(1.4 \\
1)\end{array}$ & $\begin{array}{l}\mathrm{t}(36)=4.105, \mathrm{p}=0.0 \\
00\end{array}$ \\
\hline $\begin{array}{l}\text { Constell } \\
\text { ation }\end{array}$ & 5.24 & $5.23(1.38)$ & $\begin{array}{l}4.20(1.8 \\
6)\end{array}$ & $\begin{array}{l}\mathrm{t}(29)=2.589, \mathrm{p}=0.0 \\
15\end{array}$ \\
\hline Mean & 5.39 & $5.45(1.04)$ & $\begin{array}{l}4.60(1.6 \\
1)\end{array}$ & $\begin{array}{l}\mathrm{t}(29)=2.589, \mathrm{p}=0.0 \\
15\end{array}$ \\
\hline
\end{tabular}

Skala Likert digunakan untuk mengukur ekspresi peta niat yaitu seberapa baik niat mengungkapkan pertanyaan yang sesuai pada hubungan antara kata pencarian, pertanyaan dan niat. Efektivitas pengguna diukur menggunakan paired t-test. Kontribusi utama dari penelitian ini adalah dapat secara otomatis mengekstrak niat pencarian pengguna berdasarkan pada log pencarian daripada kata kunci pada permintaan, ini memungkinkan studi dasar yang dapat memberikan panduan permintaan untuk pencarian yang mudah dan percobaan mencapai hasil yang dapat diandalkan pada data praktis dari mesin pencari saat ini dari data teoritis. Studi masa depan dapat fokus pada struktur representasi peta niat dalam aspek layanan pengguna.

\section{E. Bag of Words sebagai Fitur}

Penelitian ini mengusulkan teknik berdasarkan pembelajaran mesin yang melibatkan tiga tahap [7]:

- Pelatihan Pengguna - Ini adalah proses mengambil masukan dari pengguna untuk menyampaikan harapannya dari permintaan pencarian.

- Menyimpulkan pengetahuan dari set pelatihan.

- Menggunakan pengetahuan ini untuk berpikir dan menyaring hasil pencarian baru untuk menentukan klasifikasi relevansi mereka.

Pelatihan pengguna

Pengguna harus melatih sistem dengan melakukan klasifikasi biner yaitu dia harus mengklasifikasikan setiap hasil pencarian sebagai "relevan" atau "tidak relevan" sesuai dengan kebutuhannya untuk permintaan pencarian. Setiap hasil pencarian yang ditandai sebagai relevan atau tidak relevan oleh pengguna disebut sebagai contoh pelatihan.

Menyimpulkan Pengetahuan dari Pelatihan mengatur Masukan pelatihan dari pengguna disimpan sebagai set pelatihan adalah data mentah. Data mentah ini perlu diproses dan diwakili dalam bentuk yang dapat digunakan untuk menyimpulkan pengetahuan dari itu. Ini melibatkan beberapa langkah:

- Mengumpulkan Informasi dari Perangkat Pelatihan - Daftar kata-kata yang terjadi di semua hasil dalam set pelatihan disiapkan. Daftar ini berisi ribuan kata.

- Pembersihan data - Daftar kata yang diperoleh di langkah di atas berisi bagian-bagian pidato, dan karakter ucapan yang perlu dihapus dari data pelatihan.

- Matriks Keputusan - Matriks Keputusan dibangun yang terdiri dari daftar hasil pencarian, klasifikasi relevansi mereka dan kemunculan semua atribut dalam hasil pencarian.

- Decision Tree- Fakta-fakta yang dinyatakan dalam matriks keputusan perlu dipelajari oleh sistem untuk menyimpulkan pengetahuan dari itu. Algoritma yang disebut ID3 (Iterative Dichotomizer 3) digunakan untuk mempelajari fakta dengan membangun pohon keputusan [15]. 
Masukan ke langkah ini adalah matriks keputusan dan output akan menjadi pohon keputusan di mana daun node mewakili klasifikasi relevansi dan node non-daun mewakili node keputusan, yang merupakan atribut.

Penalaran dan Pemfilteran hasil pencarian baru

Pencarian top-down di pohon keputusan dilakukan ketika hasil pencarian baru dipertimbangkan. Pertama, atribut pada akar pohon keputusan dilihat hasilnya. Jika ditemukan, maka atribut pada penerus yang tepat terlihat, kalau tidak atribut pada penerus kiri dicari. Demikian pula, dari atas ke bawah, atribut dalam pohon secara iteratif melihat di hasil pencarian baru hingga daun pohon tercapai, sehingga status relevansi hasil pencarian diperoleh.

Arah pekerjaan masa depan dapat menggunakan umpan balik implisit jika pengguna tidak tertarik untuk secara eksplisit melatih sistem atau sistem dapat diintegrasikan dengan sistem lain atau dengan menggabungkan umpan balik implisit dengan umpan balik eksplisit.

\section{KESIMPULAN}

Dalam tulisan ini, kami telah membahas berbagai fitur dan teknik pembelajaran mesin yang menyaring hasil sesuai dengan niat pencarian pengguna. Niat pencarian pengguna dapat dikomunikasikan ke sistem dalam dua cara: umpan balik implisit dan umpan balik eksplisit. Umpan balik implisit terdiri dari perilaku pengguna dan aktivitas seperti kunjungan halamannya, penelusuran, dan aktivitas penjelajahan. Dalam penelitian [4] - [5] [6] data klik-tayang, URL dan log pencarian digunakan, umpan balik implisit digunakan dalam pekerjaan mereka. Keuntungan menggunakan umpan balik implisit adalah bahwa ia tidak mengganggu aktivitas pengguna tetapi kerugiannya adalah bahwa itu hanya penilaian sistem dari niat pengguna, sehingga mungkin tidak selalu akurat mencerminkan niat pengguna dalam setiap kasus. Di antara [4], [5] dan [6], [5] lebih cepat karena hanya menggunakan fitur URL dan tidak perlu mengambil halaman web dan memrosesnya terlebih dahulu. Dalam umpan balik eksplisit, pengguna secara eksplisit memberikan preferensinya sehingga lebih akurat daripada umpan balik implisit. Pada [3] dan [7] pengguna melatih sistem, sehingga umpan balik eksplisit dari pekerjaan mereka digunakan. Kehilangan umpan balik eksplisit adalah bahwa pengguna harus melatih sistem, sehingga ada waktu overhead pelatihan tetapi sistem menebusnya dengan menghemat waktu dan usaha yang lebih besar karena akurasi yang tinggi dari hasil yang difilter. Tinjauan menunjukkan bahwa feedforward / backpropagation jaringan saraf (FF / BP / NN) dan mesin vektor Dukungan (SVM-WEB) classifier melakukan lebih baik daripada pendekatan berdasarkan kata kunci, pendekatan berbasis leksikon, RBF dan Naïve Bayes classifier.

\section{REFERENSI}

[1] O. Etzioni," The world wide web: Quagmire or gold mine", Communications of the ACM, 39(11):65-68,1996.

[2] https://en.wikipedia.org/wiki/Machine_learning

[3] Michael Chau, Hsinchun Chen,"A machine learning approach to web page filtering using content and structure analysis",Decision Support Systems 44(2008) 482-494,2007

[4] TarannumBibi,Pratiksha Dixit,RutujaGhule, RohiniJadhav," Web search personalization using machine learning techniques",IEEE,2014 
[5] M.Indra Devi, Dr.R.Rajaram and K.Selvakuberan,"Machine learning techniques for automated web page classification using URL features",International conference on computational Intelligence and Multimedia Applications 2007,IEEE.

[6] Kinam Park, Taemin Lee; Soonyoung Jung; Sangyep Nam; Heuiseok Lim,"Extracting Search Intentions from Web Search Logs", Information Technology Convergence and Services (ITCS),Pages: $1-6$,IEEE,2010.

[7] Varun Gupta, Neeraj Garg and Tarun Gupta, "Search Bot:Search Intention Based Filtering Using Decision Tree Based Technique", Third International Conference on Intelligent Syatems Modelling and Simulation,IEEE,2012.

[8] Xiaoguang Qi and Brian D. Davison,"Web page classification:features and algorithms", ACM computing surveys, vol.41,No. 2,Article 12(February 2009). [9] J.Kleinberg, "Authoritative sources in a hyperlinked environment", Proceedings of the ACM-SIAM Symposium on Discrete Algorithms, 1998. [10] S.Brin, L.Page, "The anatomy of a large-scale hypertextual web search engine", Proceedings of the 7th International World Wide Web Conference, Brisbane, Australia, Apr 1998. [11] M.Chau, H.Chen, "Comparison of three vertical search spiders", IEEE Computer 36(5) (2003a) 56-62.

[12] C.J. van Rijsbergen," Information Retrieval", Second edition, Butterworths, London, 1979. [13] K.Tolle, H. Chen," Comparing noun phrasing techniques for use with medical digital library tools", Journal of the American Society for Information Science 51(4) (2000) 352-370. [14] M.F. Porter, "An algorithm for suffix stripping", Program 14 (3) (1980) 130-137. [15] J.R. Quinlan,'Induction of Decision Tree",Machine Learning,Vol. 1,pp 81-106,1986. 